\title{
Phytoremediation of cyanide and iron cyanide complexes and the mechanisms involved
}

\author{
Wing-Yee $\mathrm{Au}^{1}$, Xiao-Zhang $\mathrm{Yu}^{2}$ and Ji-Dong Gu${ }^{1 *}$ \\ ${ }^{1}$ School of Biological Sciences, The University of Hong Kong, Pokfulam Road, Hong Kong, China \\ 2 The Guangxi Key Laboratory of Theory \& Technology for Environmental Pollution Control, College of Environmental Science \& \\ Engineering, Guilin University of Technology, Guilin 541004, China
}

\begin{abstract}
This paper reviewed the physical and chemical properties of cyanide species - free cyanide and iron-cyanide complexes, and the potential of cyanide phytoremediation with reference to the phytotoxicity of free cyanide and iron-cyanide complexes in plants. There are three possible pathways, which are $\beta$-cyanoalanine synthase, sulfur transferase and formamide hydrolase pathways, for transforming and assimilating endogenous free cyanide in plants. Iron-cyanide complexes are generally resistant to microbial and fungal degradation. It is suggested that there may be undiscovered degradation pathways involved in assimilating iron-cyanide complexes in plants; however the detailed pathways of assimilation of iron-cyanides are still unknown. While uptake of free cyanide is mainly by simple diffusion, as iron-cyanide complexes are membrane-impermeable, it is suggested that the complexes may be transported into the plants through the mode of protein mediated uptake. Upon uptake, biological fates of cyanide species vary with different species of cyanide, depending on their chemical properties and concentrations. Phytotoxicity of free cyanide in plants is much higher than that of iron-cyanide complexes as plants could generally withstand a higher concentration of iron-cyanide complexes comparing with free cyanide. However, it is still unsure if the iron-cyanide complexes are toxic themselves or if they disrupt the metabolism of plants indirectly. It is known that endogenous cyanogenic compounds play a role in providing sources of nitrogen and acting as precursors in some biochemical processes in plants. Studies suggested that exogenous cyanide species, to a certain extent, could benefit the plants through providing nutrition to them. However, there is still no study conclusively indicates that there is a direct acquisition of exogenous cyanide species by plants as their alternative source of nitrogen. Further investigations on the degradation pathways of iron-cyanide complexes and the essential enzymes involved in phyto-assimilation of iron-cyanide complexes are required for better understanding of the degradation and assimilation pathways of cyanogenic compounds in plants.
\end{abstract}

Keywords: phytoremediation; cyanide; iron cyanide complexes; cyanogenic compounds; phytotoxicity; assimilation; plants

* Correspondence to:

Ji-Dong Gu, School of Biological Sciences, The University of Hong Kong, Pokfulam Road, Hong Kong, China; E-mail: jdgu@ hku.hk

Received: January 17, 2018; Accepted: February 7, 2018; Published Online: February 25, 2018

Citation: Au, W.Y., Yu, X.Z. and Gu, J.-D., 2018, Phytoremediation of cyanide and iron cyanide complexes and the mechanisms involved. Applied Environmental Biotechnology, 3(1), 53-60. http://doi.org/10.26789/AEB.2018.01.002.

Copyright: Phytoremediation of cyanide and iron cyanide complexes and the mechanisms involved. @ 2018 Wing-Yee Au et al.. This is an Open Access article distributed under the terms of the Creative Commons Attribution-Noncommercial 4.0 International License, permitting all non-commercial use, distribution, and reproduction in any medium, provided the original work is properly cited and acknowledged.

\section{Introduction}

Cyanide is used widely in industrial processes, such as mining, extracting, manufacturing processes of gold and other precious metals, chemical synthesis for synthesizing synthetic fibers and plastics, waste treatment processes, and electroplating (Ebbs et al., 2006). It is also produced as by-products during industrial processes such as chemical synthesis, iron and steel production, etc.. Cyanide species are common contaminants presented in former industrial locations that were primarily used for purposes of electroplating or as gashouses, such as some of the "Superfund Sites" in the USA (Boening and Chew, 1999; Meeussen et al., 1994). In the USA, since 1995, cyanide has been listed as one of the top 30 compounds on the CERCLA Priority List of Hazardous Substances (Ebbs et al., 2003). Ebel et al. (2007) has also shown that effluents generated from gold mining and extraction in the tailing ponds contained up to $400 \mathrm{mg} / \mathrm{L}$ of total cyanides; of the total cyanides, they included nearly 120 $\mathrm{mg} / \mathrm{L}$ of free cyanide.

Mobility and speciation of cyanides are much affected by biotic and abiotic factors such as biological activities, redox potential, $\mathrm{pH}$, presence of organic acids, etc. (Ebbs et al., 2008). In soil or sediment, it is believed that there are inter-conversions of different cyanide species (Yu, 2015). Realizing possible solutions for cyanide contamination requires the understanding of cyanide speciation and physical and chemical properties of different forms of cyanide species. In the following, physical and chemical properties, biological fates, specific transformation and assimilation pathways of free cyanide and iron cyanide complexes in plants will be discussed in detail. 


\section{Free Cyanide and Iron-cyanide Complexes}

\subsection{Physical and Chemical Properties of Free Cyanide}

As the most toxic form of cyanide, free cyanide can exist as cyanide species - hydrogen cyanide (HCN) and cyanide anion $\left(\mathrm{CN}^{-}\right)$. $\mathrm{HCN}$ exists as gaseous form under normal environmental conditions and has a very high solubility in water. Dissolution of $\mathrm{HCN}$ in water produces weak acid, $\mathrm{HCN}(\mathrm{aq})$ with $\mathrm{pKa}=9.24$ at $25^{\circ} \mathrm{C}$ (Dzombak et al., 2006; Kjeldsen, 1999). Upon dissolution, when $\mathrm{pH}$ is lower than 7, free cyanide exists exclusively in the form of $\mathrm{HCN}(\mathrm{aq})$; at higher $\mathrm{pH}, \mathrm{HCN}(\mathrm{aq})$ dissociates in water, forming soluble cyanide anion $\left(\mathrm{CN}^{-}\right)$; and at $\mathrm{pH}$ higher than $11, \mathrm{HCN}(\mathrm{aq})$ completely dissociates to form $\mathrm{CN}^{-}$(Kjeldsen, 1999).

Endogenous free cyanide is presented in many vascular plants (Ebbs et al., 2010). The major source of endogenous free cyanide is from hydrolysis of cyanogenic glycosides, which then gives rise to hydrogen cyanide ( $\mathrm{Yu}$, 2015). Cyanogenic glycosides are organic cyanide species that present in more than 2650 cyanogenic plant species for self-defense mechanisms or as alternative forms of nitrogen for storage (Dzombak et al., 2006; Ebbs et al., 2006). Although free cyanide exhibits high toxicity, endogenous free cyanide is not likely to cause damage to the cyanogenic plants as the natural occurring level of endogenous free cyanide in plants is usually maintained to be very low (Ebbs et al., 2006). Cyanogenic plants possess high degradation capability to degrade and assimilate endogenous free cyanide (Ebbs et al., 2006), in which the rate of degradation and assimilation of endogenous free cyanide in the plants is higher comparing with that of the generation of endogenous free cyanide (Manning, 1988). There is thus not likely to be accumulation of endogenous free cyanide inside the cyanogenic plants.

\subsection{Transformation and Assimilation Path- ways of Free Cyanide in Plants}

Free cyanide is not likely to be accumulated in plant tissues of healthy plants (Larsen et al., 2005). It is thus suggested that plants could possibly degrade both endogenous and exogenous forms of free cyanide through some defined degradable pathways. Previous studies have identified three possible degradation pathways, which are $\beta$-cyanoalanine synthase, sulfur transferase, and formamide hydrolase pathways to be involved in degradation of free cyanide in plants (Yu, 2015).

\subsection{1 $\beta$-cyanoalanine Pathway}

The first metabolic step of $\beta$-cyanoalanine pathway is being shown in Figure 1 . The enzyme, $\beta$-cyanoalanine synthase, which is responsible in catalyzing precursors cysteine and hydrogen cyanide to products $\beta$-cyanoalanine and hydrogen sulfide, is a common enzyme found in all vascular plants (Yu, 2015). An enzyme which demonstrates the functions as both nitrile hydratase and nitrilase further catalyzes the conversion of $\beta$-cyanoalanine into asparagine or aspartate and ammonium (Ebbs et al., 2010). Asparagine can be converted into aspartate and ammonium by hydrolysis under the catalysis of asparaginase (Bruneau et al., 2006; Lea et al., 2007).

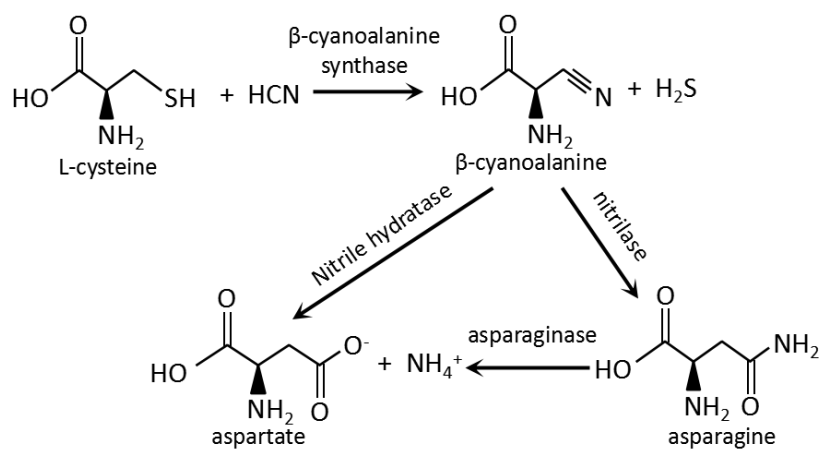

Figure 1. The first metabolic step for metabolism of cyanide through $\beta$-cyanoalanine synthase pathway; adapted from Yu (2015) with slight modification

\subsubsection{Sulfur Transferase Pathway}

The metabolism of cyanide through sulfur transferase pathway is being shown in Figure 2. The sulfur transferase pathway, also called the rhodanese pathway, converts cyanide $\left(\mathrm{CN}^{-}\right)$to a less toxic cyanide form of thiocyanate $\left(\mathrm{SCN}^{-}\right)$ under catalysis of the enzyme rhodanese (Yu, 2015).

\subsubsection{Formamide hydrolase pathway}

$\mathrm{CN}^{-}+\mathrm{S}_{2} \mathrm{O}_{3}{ }^{2-} \stackrel{\text { rhodanese }}{\longrightarrow} \mathrm{SCN}^{-}+\mathrm{SO}_{3}{ }^{2-}$

Figure 2. Metabolism of cyanide through sulfur transferase pathway; adapted directly from Yu (2015)

The metabolism of cyanide through formamide hydrolase pathway is being shown in Figure 3. Cyanide in the pathway is first converted into formamide under catalysis of the enzyme formamide hydrolase, and then subsequently results in formation of formic acid and ammonia with formaldoxime as the intermediate compound (Yu, 2015). Formamide can also be converted into formate and ammonia through direct hydrolysis under catalysis of the enzyme formamide amidohydrolase (Shirai, 1978; Miller and Conn, 1980). Formamide hydrolase pathway was recorded in Japanese apricot (Prunus mume, Sieb. et Zucc.) and loquats (Eriobotrya japonica L.). However, it has not been any record or observation of the pathway in other plants other than the two species listed above (Srivastava and Duvvuru Muni, 2010), the actual significance of the pathway to the metabolism of cyanide in vascular plants therefore remains in doubt. 


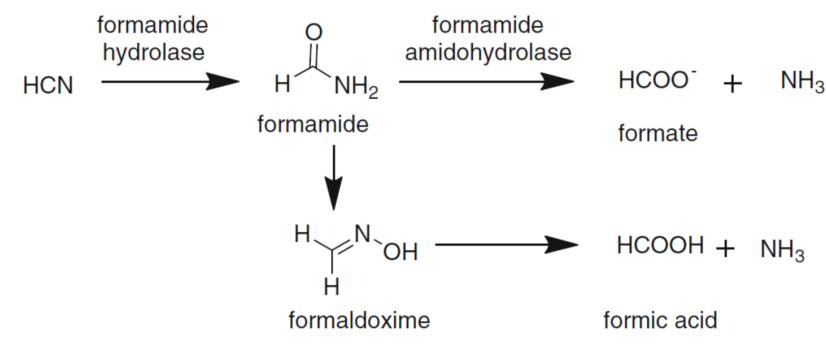

Figure 3. Metabolism of cyanide through formamide hydrolase pathway; adapted directly from Yu (2015)

\subsection{Physical and Chemical Properties of Iron- cyanide Complexes}

General description of metal-cyanide complexes: various metal cations can form soluble metal-cyanide complexes upon reacting with cyanide anions $\left(\mathrm{CN}^{-}\right)$. Weak metalcyanide complexes are the complexes that have relatively weaker bonds between metal cations and cyanide anions. They tend to dissociate readily upon slightly acidic environment and it causes the release free cyanide in the environment. It therefore raises greater concern with its toxicity in compare with strong metal-cyanide complexes. Copper cyanide species $\left(\mathrm{Cu}(\mathrm{CN})_{2}{ }^{0}, \mathrm{Cu}(\mathrm{CN})_{3}{ }^{-}, \mathrm{Cu}(\mathrm{CN})_{4}{ }^{3-}\right)$, and zinc cyanide species $\left(\mathrm{Zn}(\mathrm{CN})_{2}{ }^{0}, \mathrm{Zn}(\mathrm{CN})_{3}{ }^{-}, \mathrm{Zn}(\mathrm{CN})_{4}{ }^{2-}\right)$ are examples for weak metal-cyanide complexes. Strong metal-cyanide complexes, in contrast, are the complexes with a higher stability and are generally more resistant to dissociation under weak acidic conditions (for $\mathrm{pH} \geqslant 2$ ) (Dzombak et al., 2006). They thus have lower toxicity in compare with weak metal-cyanide complexes.Gold cyanide complex $\left(\mathrm{Au}(\mathrm{CN})_{2}{ }^{-}\right)$is one of the examples. Iron-cyanide complexes such as ferrocyanide $\left(\mathrm{Fe}(\mathrm{CN})_{6}{ }^{4-}\right)$ and ferricyanide $\left(\mathrm{Fe}(\mathrm{CN})_{6}{ }^{3-}\right)$ are also regarded as strong metalcyanide complexes. Iron-cyanide compounds can exist as more complex compound forms such as ferric-ferrocyanide $\left(\mathrm{Fe}_{4}\left(\mathrm{Fe}(\mathrm{CN})_{6}\right)_{3}\right)$, etc. Regarding biodegradation of ironcyanide complexes, they are generally rather resistant to microbial and fungal degradation (Ghosh et al., 1999; Meeussen et al., 1992).

\subsection{Transformation and Assimilation of Iron- cyanide Complexes in Plants}

Although it is obvious that degradation of iron-cyanide complexes is taking place in plants, the exact degradation pathway of iron-cyanide complexes in plants is still not yet known (Yu, 2015). There were two proposed possible transformation and assimilation pathways of iron-cyanide complexes by plants. The first was direct assimilation of iron-cyanide complexes as substrates by plants through an undiscovered pathway (Yu, 2015). The second was dissociation of iron cyanide complexes back into ferric, ferrous and cyanide ions prior to metabolism and assimilation of free cyanide by plants through $\beta$-cyanoalanine pathway (Larsen and Trapp, 2006), the pathway as described above in Figure 1. There are stud- ies demonstrated that upon uptake of iron-cyanides from the surrounding environment, iron-cyanide complexes likely maintain as their original complex forms inside the plant materials (Yu, 2015). Studies by Yu et al. (2011; 2012) also demonstrated that there were only slight changes in $\beta$-cyanoalanine synthase upon treating the plants with ironcyanides. $\mathrm{Yu}$ (2015) in his review commented that there is an indication that dissociation of iron cyanide complexes prior to assimilation may not be necessary and it is more likely that the iron cyanide complexes are transformed and assimilated in plants through an undiscovered pathway instead of $\beta$-cyanoalanine pathway.

\subsection{Biological Fate and Uptake of Exogenous Free Cyanide and Iron-cyanide Com- plexes by Plants}

Upon uptake by roots, the exogenous cyanide species can stay as unchanged original forms, bind to other compounds or be transformed through degradation, detoxification or assimilation (Bushey et al., 2006). The biological fate of different cyanide species is hugely dependent on the chemical properties and concentrations of the cyanide species (Yu, 2015). Phytotoxic effects to the plants will only appear when assimilation rates of the cyanide species are much slower than that of accumulation rates (Larsen et al., 2005). As aforementioned, the transformation and assimilation of free cyanide in plants are most likely through the defined pathways, such as $\beta$-cyanoalanine pathway in vascular plants; while the assimilation of iron-cyanide complexes in plants, as some studies suggested, may be through undiscovered degradation pathways. Exogenous free cyanide is believed to be taken by plants through simple diffusion while exogenous iron cyanide complexes are believed to be impermeable to membrane and therefore studies have suggested the uptake of iron cyanide complexes is through the mode of protein-mediated uptake (Yu, 2015).

\section{Phytoremediation}

Phytoremediation is commonly referred as the remediation method in utilizing vascular plants, algae and fungi for removing contaminants from the environment through metabolism or sequestration, or by inducing microorganisms to degrade contaminants in soil (McCutcheon and Schnoor, 2003). Polluted sites with low to medium contamination levels would be suitable for phytoremediation (Yu, 2015; Yu and Feng, 2016; Yu and Zhang, 2017). Phytoremediation is the technique that could simultaneously act on a wide variety of media and contaminants (Yu, 2015). It comprises of five technologies, which are phytoextraction, rhizofiltration, phytostabilization, phytovolatization and phytodegradation (Cunningham et al., 1995).

Phytoextraction is to extract contaminants from soil to the aerial tissues of the plants. Contaminants could then be eliminated from the polluted site through harvesting the aboveground plant tissues. This technology depends on factors 
such as bioavailability of the contaminants, possible concentration of contaminants to be accumulated in aerial tissues of the plants, and biomass production of the plants (Ebbs et al., 2006). Rhizofiltration is to eliminate contaminants from polluted waters through plant roots. The technology is effective in eliminating cationic contaminants (Ebbs et al., 2006). Examples of plants used for rhizofiltration include sunflower (Helianthus annus L.) and Indian mustard (Brassica juncea L.) (Dushenkov et al., 1995; Dushenkov et al., 1997).

Phytostabilization utilizes plants to modify the physicochemical conditions of the rhizosphere, and thereby stabilizing contaminants through making the contaminants, such as chromium and uranium become less soluble, mobile or toxic (Lytle et al., 1998). The technology can also be done through sequestration of contaminants in the roots of the contaminant-tolerant grasses (Ebbs et al., 2006).

Phytovolatilization is to utilize plants to convert contaminants to their volatile forms and then release the volatile forms to the air. The technology only applies to the contaminants in which their volatile forms are less toxic than their original forms (Ebbs et al., 2006). Examples of contaminants to be remediated include selenium (de Souza et al., 1998; Pilon-Smits et al., 1998) and volatile organic compounds (Meagher et al., 2000; Orchard et al., 2000).

Phytodegradation is to utilize plants to convert mutable contaminants to their other forms through metabolism. Degradation may be incomplete for some contaminants; the effectiveness of phytodegradation thus varies with different contaminants (Ebbs et al., 2006). The examples of mutable contaminants in which phytodegradation is effective include hydrocarbons, ammunition wastes and chlorinated solvents, etc. (Ebbs et al., 2006).

\subsection{Cyanide Phytoremediation}

Cyanide phytoremediation can utilize multiple phytoremediation technologies as stated above (Ebbs et al., 2006). It can be applied to both aqueous and terrestrial systems (Ebbs et al., 2006).

\subsection{Phytotoxicity of Cyanide Species in Plants}

The transport and assimilation capability of free cyanide and iron cyanide complexes of plants hugely depends on their genetic compositions (Yu, 2015). With regard to different exogenous species of cyanide with different levels of bioavailability, plants will show different physiological and biochemical responses, resulting in difference in the uptake, transport, assimilation and toxicity of different cyanide species (Yu, 2015).

Phytotoxicity of cyanide species is seen to have multiple effects on plants, ranging from reduction in growth rate (growth rate is dependent on transpiration rate, chlorophyll content, biomass, etc.), to inhibition of enzymatic pathways of plants (Yu, 2015). In terms of accumulation of cyanide species, although roots are in general the major site for accumulation of cyanides (2012), the fate for different cyanide species in plants is likely to be different as different species of cyanide tend to have different distribution patterns in the plant materials (Yu, 2015). It is observed that the mitochondrial alternative oxidase that presents and activates when the plants are exposed to cyanide is partly responsible for the resistance of plants to cyanide toxicity (Ebbs et al., 2006).

In terms of phytotoxicity of free cyanide in plants, free cyanide is known to cause disruption to the metabolism of plants primarily through binding with sulfur, iron, coppercontaining enzymes and proteins (Ebbs et al., 2003; Schnepp, 2006; Barillo, 2009) or blocking the mitochondrial electron transport system through forming complex with iron in the terminal cytochrome (Cooper and Brown, 2008).

\subsection{Phytotoxicity of Exogenous Free Cyanide in Plants}

In response to different concentration of free cyanide, different species of plants exhibited different level of phytotoxicity to free cyanide. In general, plants could tolerate a much higher concentration of free cyanide when free cyanide is being applied to the soil rather than the hydroponic solution. The major reason may be due to some free cyanide will react with or bind to chemical substances in the soil to form complexes, causing immobilization or stabilization of some free cyanide in the soil; thus lessening the total free cyanide that is bioavailable to the plants in the soil.

With reference to previous studies, in hydroponic solution, mouse-ear cress (Arabidopsis thaliana) exhibited no toxic effects when exposed to $26 \mu \mathrm{g} \mathrm{CN} / \mathrm{L}$ of free cyanide (McMahon-Smith and Arteca, 2000). For basket willows (Salix viminalis), the $\mathrm{EC}_{50}$ values were shown to be $1.5 \mathrm{mg}$ CN/L (Trapp et al., 2001, cited in Ebbs et al., 2006 ). Basket willows exhibited toxic effects with reduction in transpiration by $50 \%$ when exposed to $2 \mathrm{mg} \mathrm{CN} / \mathrm{L}$ of free cyanide for 3 days (Larsen and Pirandello, 2004) When being exposed to equal to greater than $20 \mathrm{mg} \mathrm{CN} / \mathrm{L}$ of free cyanide, it would result in immediate death (Larsen and Pirandello, 2004). For weeping willows (Salix bablylonica L.), the $\mathrm{EC}_{50}$ values were shown to be within the range of 3.27 to 8.34 $\mathrm{mg} \mathrm{CN} / \mathrm{L}$ of free cyanide, with the rate of transpiration as the sensitive indicator of toxicity (Yu et al., 2005). Diamond willows (Salix eriocephala var. Michaux), as compared with other willows, seem to have the ability to tolerate a relatively higher concentration of exogenous free cyanide. For basket willows, they already exhibited toxic effects when exposed to $2 \mathrm{mg} \mathrm{CN} / \mathrm{L}$ of free cyanide for 3 days (Larsen and Pirandello, 2004); diamond willows, on the other hand, exhibited no negative effects on both the transpiration rates and growth rates when exposed to $2 \mathrm{mg} \mathrm{CN} / \mathrm{L}$ of free cyanide for 20 days (Ebbs et al., 2003).

In soil, from the study by Wallace et al. (1977), bush bean (Phaseolus vulgaris L.) wilted after exposed to $25 \mathrm{mg}$ $\mathrm{NaCN} / \mathrm{kg}$ of soils (dried weight) for 3 days. There was pronounced growth reduction when the bush bean exposed to $100 \mathrm{mg} \mathrm{NaCN} / \mathrm{kg}$ of soils (dried weight) (Wallace et al. 1977). When exposed to $100 \mathrm{mg} \mathrm{NaCN} / \mathrm{kg}$ of soils (dried weight) for 9 days, it resulted in absolute lethality of the bush 
bean (Wallace et al. 1977).

From previous studies, positive effects were recorded from several species of plants when they were exposed to a certain concentration of exogenous free cyanide. For weeping willows (Salix babylonica L.), they exhibited positive growth when exposed to less than or equal to $4.74 \mathrm{mg} \mathrm{CN} / \mathrm{L}$ of free cyanide (Yu et al., 2007). For Sorghum (Sorghum bicolor), no toxic effect but an increase in rate of transpiration was recorded when the plants were exposed to free cyanide concentration in the range of 20 to $50 \mathrm{mg} \mathrm{CN} / \mathrm{L}$ in soil (Trapp et al., 2003).

\subsection{Phytotoxicity of Exogenous Iron-cyanide Complexes in Plants}

As aforementioned, the degradation and assimilation pathways of iron-cyanides in plants still remain questionable. Iron-cyanide complexes are considered to be less toxic to plants when comparing with free cyanide (Yu, 2015). Plants in general could withstand a much higher concentration of iron-cyanide complexes than free cyanide (Yu, 2015).

There were studies demonstrated that solid forms of ironcyanides, such as Prussian blue and Turnbull's blue, would be coated on the roots of plants when exposing the plants to ferrocyanide (Ebbs et al., 2006). Such plants include diamond willows (Salix eriocephala var. Michaux), tomato (Lycopersicum esculentum L.), indian mustard (Brassica juncea L.) and various grasses such as foxtail (Setaria sp.), barley (Hordeum vulgare L.) and wild cane (Sorghum bicolor L.) (Reeves, 2000; Samiotakis, 2002; Ebbs et al., 2006). Reeves (2000) has shown that when exposed to $8 \mathrm{mg} / \mathrm{L}$ of ferro-cyanide in hydroponic solution, the roots of diamond willows were coated with heavy precipitation of cyanide solids. With such thick coating, there was a decrease in water use, biomass and area of the leaves of diamond willows (Reeves, 2000). Ebbs et al. (2006) also demonstrated that when grasses including foxtail, barley and wild cane were exposed to ferro-cyanide with concentrations ranging from 30 to $143 \mathrm{mg} / \mathrm{L}$, after 14 to 28 days of exposure, similar coatings with precipitation of cyanide solids on the roots of the plants as Reeves (2000) were observed and recorded. However, it is still not sure if the ferro-cyanide are themselves toxic to the plants, or if the negative impacts on plants such as loss of water use, biomass and leaves area with ferrocyanide exposure were simply due to the indirect effect of precipitation of cyanide solids on roots in blocking the movement of water and solutes across the cell walls of the roots (Ebbs et al., 2006).

With reference to previous studies, in hydroponic solutions, basket willows (Salix viminalis) did not show any sign of toxicity when exposed to $10 \mathrm{mg} \mathrm{CN} / \mathrm{L}$ of ferro-cyanide or ferri-cyanide (Larsen and Trapp, 2006). When comparing with the results of basket willows under exposure of free cyanide in hydroponic solutions, under free cyanide concentration of $2 \mathrm{mg} \mathrm{CN} / \mathrm{L}$ for 3 days, basket willows already exhibited phytotoxicity effects (Larsen and Pirandello, 2004). The results indicated that basket willows are likely to be more resistant to much higher concentration of iron-cyanide complexes than free cyanide. Other studies investigated on the phytotoxicity of iron-cyanide complexes on Balsam poplars (Populus trichocarpa L.). When exposed to $5.4 \mathrm{mg} / \mathrm{L}$ of Prussian blue, no toxic effect was observed in Balsam poplars (Larsen et al., 2005; Kang et al., 2007); there was a slight decrease in rate of transpiration when the plants were exposed to $27 \mathrm{mg} \mathrm{CN} / \mathrm{L}$ of Prussian blue (Larsen et al., 2005; Kang et al., 2007); when exposed to even higher concentrations such as 1350 or even $2500 \mathrm{mg} \mathrm{CN} / \mathrm{L}$ of Prussian blue, studies have shown that Balsam poplars would still be able to survive but there would be a significant reduction in the rates of growth and transpiration of the plants (Larsen et al., 2005; Kang et al., 2007; Wallace et al. 1977).

In soil, when exposed to $50 \mathrm{mg} / \mathrm{L}$ of ferro-cyanide, barley, oat and wild cane did not show any toxic effects or any loss of the biomass (Samiotakis and Ebbs, 2004).

\subsection{Benefits of phytoremediation to plants}

It is believed that endogenous cyanogenic compounds play a critical role in providing source of nitrogen and acting as a precursor for some biochemical processes in plants (Niedźwiedź-Siegień, 1988; Yu, 2015). For instance, endogenous cyanogenic glycosides are a source of nitrogen for cyanogenic plants and they also act as a precursor for synthesis of amino acids and proteins during the development of the seedlings (Niedźwiedź-Siegień, 1988). Both asparagine and aspartate generated from $\beta$-cyanoalanine pathway also act as an extra ammonium source to the plants (Yu, 2015).

For exogenous cyanide species that are the targets for phytoremediation, although there is still no study conclusively indicates that exogenous cyanide species can be directly assimilated by the plants to act as an alternative nitrogen source to the plants, studies have proven that to a certain extent, exogenous cyanide species does benefit plant nutrition (Yu, 2015). Machingura and Ebbs (2010) in their study suggested that under nitrogen-limiting conditions and non-toxic exogenous cyanide concentrations of, wheat can utilize exogenous cyanide to act as their alternate source of nitrogen.

\section{Conclusions and Future Research Directions}

In this review, physical and chemical properties of free cyanide and iron-cyanide complexes were discussed. Three transformation and assimilation pathways of free cyanide in plants were also reviewed. It is suggested that there are undiscovered degradation and assimilation pathways of ironcyanide complexes in plants. Phytotoxicity of free cyanide is higher than that of iron cyanide complexes, in which the plants could generally withstand much higher concentration of iron cyanide complexes when compared with free cyanide. This review also covered the possible benefits for plants in utilizing endogenous and exogenous cyanide as their sources of nitrogen. 
Although cyanide phytoremediation has been under intensive research in recent years, uncertainties still remain in a few of the study areas, including the physicochemical mechanisms of cyanide species in the environment, the biological mechanisms involved in transport and assimilation of free cyanide within the plants. It is also uncertain of the rule that governs the capacity for cyanogenic and non-cyanogenic plants to phytoremediate free cyanide, the fate of iron cyanide complexes in plants upon uptake, the contribution of exogenous cyanide species as an alternate source of nitrogen, and the factors that affect the uptake rates of cyanide by plants.

It is expected that for future research of phytoremediation, it should focus on these aspects: i) The detailed assimilation and degradation pathways of iron cyanide complexes in plants through utilizing $\mathrm{N}^{15}$ labeled ferro-cyanide and ferricyanide for quantitatively locating the fate and tracking the transport of iron cyanide complexes in plant tissues upon uptake; ii) The essential enzymes involved in phytoassimilation of iron cyanide complexes in plants and the respective DNA and proteomic expression of the enzymes, in order to have a better and a more complete understanding of the assimilation pathways of cyanogenic compounds in plants.

The recent momentum of biodegradation and transformation of pollutants has been obvious in developing countries, including Brazil, China, India as examples, but little innovation or breakthroughs have been discovered (Gu, 2016). It is important to keep in mind that new technological development will be based on new original research on new discoveries and such focus shall be made in future research.

\section{Acknowledgements}

We would like to thank Mr. Xiaobo Liu for enhancement of the figures for better visual presentation.

\section{Conflict of Interest}

All authors declare that they have no conflict of interest.

\section{Ethical Approval}

This article does not contain any studies with human participants or animals performed by any of the authors.

\section{References}

Barillo, D.J., 2009. Diagnosis and treatment of cyanide toxicity. Journal of Burn Care \& Research, 30(1), 148-152. https://doi.org/10.1097/BCR.0b013e3181923b91

Boening, D.W. and Chew, C.M., 1999. A critical review: general toxicity and environmental fate of three aqueous cyanide ions and associated ligands. Water Air and Soil Pollution, 109(1-4), 67-79.

https://doi.org/10.1023/A:1005005117439
Bruneau, L., Chapman, R. and Marsolais, F., 2006. Co-occurrence of both L-asparaginase subtypes in Arabidopsis: At3g16150 encodes a $\mathrm{K}^{+}$-dependent L-asparaginase. Planta, 224(3), 668-679. https://doi.org/10.1007/s00425-006-0245-9

Bushey, J.T., Ebbs, S.D. and Dzombak, D., 2006. Development of a plant uptake model for cyanide. International Journal of Phytoremediation, 8(1), 25-43. https://doi.org/10.1080/15226510500507151

Cooper, C.E. and Brown, G.C., 2008. The inhibition of mitochondrial cytochrome oxidase by the gases carbon monoxide, nitric oxide, hydrogen cyanide and hydrogen sulfide: chemical mechanism and physiological significance. Journal of Bioenergetics and Biomembranes, 40, 533-539. https://doi.org/10.1007/s10863-008-9166-6

Cunningham, S.D., Nanda Berti, W.R. and Huang, J.W., 1995. Phytoremediation of contaminated soils. Trends in Biotechnology, 13(9), 393-397. http://dx.doi.org/10.1016/S0167-7799(00)88987-8

de Souza, M.P., Pilon-Smits, E.A.H., Lytle, C.M., Hwang, S., Tai, J., Honma, T.S.U., Yeh, L. and Terry, N., 1998. Rate limiting steps in selenium assimilation and volatilization by Indian mustard. Plant Physiology, 117(4), 1487-1494. https://doi.org/10.1104/pp.117.4.1487

Dushenkov, V., Kumar, P.B.A.N., Motto, H. and Raskin, I., 1995a. Rhizofiltration :the use of plants to remove heavy metals from aqueous streams. Environmental Science \& Technology, 29(5), 1239-1245. https://doi.org/10.1021/es00005a015

Dushenkov, S., Vasudev, D., Kapulnik Y., Gleba, D., Fleisher,D., Tin, K.C. and Ensley, B., 1997. Removal of uranium from water using terrestrial plants, Environmental Science \& Technology, 31(12), 3468-3474. https://doi.org/10.1021/es9702201

Dzombak, D.A., Ghosh, R.S., Wong-Chong, G.M. and Smith, J.R. (2006) Separation technologies for treatment of cyanide. pp. 413-435. In: Dzombak DA, Ghosh RS and Wong-Chong GM (eds), Cyanide in Water and Soil: Chemistry, Risk, and Management. CRC Press, Taylor \& Francis Group, Boca Raton.

Ebbs, S.D., Bushey, J., Poston, S., Kosma, D., Samiotakis, M. and Dzombak, D., 2003. Transport and metabolism of free cyanide and iron cyanide complexes by willow. Plant, Cell \& Environment, 26(9), 1467-1478. https://doi.org/10.1046/j.0016-8025.2003.01069.x

Ebbs, S.D., Kosma, D.K., Nielson, E.H., Machingura, M., Baker, A.J. and Woodrow, I.E., 2010. Nitrogen supply and cyanide concentration influence the enrichment of nitrogen from cyanide in wheat (Triticum aestivum L.) and sorghum (Sorghum bicolor L.). Plant, Cell \& Environment, 33(7), 1152-1160. https://doi.org/10.1111/j.1365-3040.2010.02136.x

Ebbs, S.D., Piccinin, R.C., Goodger, J.Q.D., Kolev, S.D., Woodrow, I.E. and Baker, A.J.M., 2008. Transport of ferrocyanide by two eucalypt species and sorghum. International Journal of Phytoremediation, 10(4), 343-357. https://doi.org/10.1080/15226510802096242

Ebbs, S.D., Wong-Chong, G.M., Bond, B.S., Bushy, J.T. and Neuhauser, E.F. (2006) Biological transformation of cyanide water and soil. pp. 93-122. In: Dzombak DA, Ghosh RS and Wong-Chong GM (eds), Cyanide in Water and Soil: Chemistry, Risk, and Management. CRC Press, Taylor \& Francis Group, Boca Raton. 
Ebel, M., Evangelou, M.W.H. and Schaeffer, A., 2007. Cyanide phytoremediation by water hyacinths (Eichhornia crassipes). Chemosphere, 66(5), 816-823. https://doi.org/10.1016/j.chemosphere.2006.06.041

Ghosh, R.S., Dzombak, D.A., Luthy, R.G. and Nakles, D.V., 1999. Subsurface fate and transport of cyanide species at a manufactured-gas plant site. Water Environment Research, 71(6), 1205-1216. http://www.jstor.org/stable/25045303

Gu, J.-D., 2016. Biodegradation testing: so many tests but very little new innovation. Applied Environmental Biotechnology, 1(1), 92-95. http://doi.org/10.18063/AEB.2016.01.007

Kang, D.H., Hong, L.Y., Schwab, A.P. and Banks, M.K., 2007. Removal of Prussian blue from contaminated soil in the rhizosphere of cyanogenic plants. Chemosphere, 69(9), 14921498. https://doi.org/10.1016/j.chemosphere.2007.04.052

Kjeldsen, P., 1999. Behaviour of cyanides in soil and groundwater: a review. Water, Air, and Soil Pollution, 115(1-4), 279-308. https://doi.org/10.1023/A:1005145324157

Larsen, M., Trapp, S. and Pirandello, A., 2004. Removal of cyanide by woody plants. Chemosphere, 54(3), 325-333. https://doi.org/10.1016/S0045-6535(03)00662-3

Larsen, M. and Trapp, S., 2006. Uptake of iron cyanide complexes into willow trees. Environmental Science \& Technology, 40(6), 1956-1961. https://doi.org/10.1021/es051224q

Larsen, M., Ucisik, A.S. and Trapp, S., 2005. Uptake, metabolism, accumulation and toxicity of cyanide in willow trees. Environmental Science \& Technology, 39(7), 2135-2142. https://doi.org/10.1021/es048799s

Lea, P.J., Sodek, L., Parry, M.A.J., Shewry, P.R. and Halford, N.G., 2007. Asparagine in plants. Annals of Applied Biology, 150(1), 1-26. https://doi.org/10.1111/j.1744-7348.2006.00104.x

Lytle, C.M., Lytle, F.W., Yang, N., Qian, J.H., Hansen, D., Zayed, A. and Terry, N., 1998. Reduction of $\mathrm{Cr}(\mathrm{VI})$ to $\mathrm{Cr}$ (III) by wetland plants: potential for in situ heavy metal detoxification. Environmental Science \& Technology, 32(20), 3087-3093. https://doi.org/10.1021/es980089x

Manning, K. (1988) Detoxification of cyanide by plants and hormone action. pp. 92-104. In: Evered D and Hanett S (eds), Cyanide Compounds in Biology.John Wiley \& Sons Ltd, Chichester, UK.

Machingura, M. and Ebbs, S.D., 2010. Increased $\beta$-cyanoalanine synthase and asparaginase activity in nitrogen-deprived wheat exposed to cyanide. Journal of Plant Nutrition and Soil Science, 173(6), 808-810. https://doi.org/10.1002/jpln.201000164

McMahon Smith, J. and Arteca, R.N., 2000. Molecular control of ethylene production by cyanide in Arabidopsis thaliana. Physiologia Plantarum, 109(2), 180-187. https://doi.org/10.1034/j.1399-3054.2000.100210.x

McCutcheon, S.C. and Schnoor, J.L. (2003) Overview of phytotransformation and control of wastes. pp. 3-58. In: McCutcheon SC and Schnoor JL (eds), Phytoremediation: Transformation and Control of Contaminants. John Wiley \& Sons, Inc., Hoboken, New Jersey.

Meagher, R.B., Ruph, C.L., Candasamy, M.K., Gragson, G. and Wang, N.J. (2000) Engineered phytoremediation of mercury pollution in soil and water using bacterial genes. pp. 201-220. In: Terry $\mathrm{N}$ and Bañuelos GS (eds), Phytoremediation of Contaminated Soil and Water. CRC Press, USA.
Meeussen, J.C.L., Keizer, M.G. and De Haan, F.A.M., 1992. Chemical stability and decomposition rate of iron cyanide complexes in soil solutions. Environmental Science \& Technology, 26(3), 511-516. https://doi.org/10.1021/es00027a010

Meeussen, J.C.L, Keizer, M.G., van Riemsdijk, W.H. and de Haan, F.A.M., 1994. Solubility of cyanide in contaminated soils. Journal of Environmental Quality, 23(4), 785-792. https://doi.org/10.2134/jeq1994.00472425002300040024x

Miller, J.M. and Conn, E.E., 1980. Metabolism of hydrogen cyanide by higher plants. Plant Physiology, 65(6), 11991202. https://doi.org/10.1104/pp.65.6.1199

Niedźwiedź-Siegień, I., 1998. Cyanogenic glucosides in Linum usitatissimum. Phytochemistry, 49(1), 59-63. https://doi.org/10.1016/S0031-9422(97)00953-9

Orchard, B.J., Doucette, W.J., Chard, J.K. and Bugbee, B., 2000. Uptake of trichloroethylene by hybrid poplar trees grown hydroponically in flow-through plant growth chambers. Environmental Toxicology and Chemistry, 19(4), 895-903. https://doi.org/10.1002/etc.5620190416

Pilon-Smits, E.A.H., Souza, M.D., Lytle, C.M., Shang, C., Lugo, T. and Terry, N., 1998. Selenium volatilization and assimilation by hybrid poplar (Populus tremula $\mathrm{x}$ alba). Journal of Experimental Botany, 49(328), 1889-1892. https://doi.org/10.1093/jxb/49.328.1889

Reeves, M.K., 2000. Treatment of fluoride and iron cyanides using willow: a greenhouse feasibility study. M.S. thesis, Cornell University.

Samiotakis, M., 2002. Uptake and assimilation of iron cyanide by different plant species. M.S. thesis, Southern Illinois University Carbondale.

Samiotakis, M. and Ebbs, S.D., 2004. Possible evidence for transport of an iron cyanide complex by plants. Environmental Pollution, 127(2), 169-173. https://doi.org/10.1016/j.envpol.2003.08.002

Schnepp, R., 2006. Cyanide: sources, perceptions, and risks. Journal of Emergency Nursing, 32(4), S3-S7. http://dx.doi.org/10.1016/j.jen.2006.05.008

Shirai, R., 1978. Study on cyanide metabolizing activity in mesocarp of Rosaceae. Journal of the College of Arts and Sciences, Chiba University, B(11), 11-33.

Srivastava A.C. and Duvvuru Muni R.R. (2010) Phytoremediation of cyanide. pp. 399-426. In: Ashraf M, Ozturk MSA, Ahmad M (eds), Plant Adaptation and Phytoremediation. Springer, Dordrecht. https://doi.org/10.1007/978-90-481-9370-7_18

Trapp, S.A.J. and Christiansen, H. (2003) Phytoremediation of cyanide-polluted soils. pp. 829-862. In: McCutcheon SC, Schnoor JL (eds), Phytoremediation: Transformation and Control of Contaminants. John Wiley \& Sons, Inc., Hoboken, New Jersey.

Wallace, A. Cha, J.W. and Mueller, R.T., 1977. Cyanide effects on transport of trace materials in plants. Communication in Soil Science \& Plant Analysis 8(9), 709-712. https://doi.org/10.1080/00103627709366763

Yu, X.Z., 2015. Uptake, assimilation and toxicity of cyanogenic compounds in plants: facts and fiction. International Journal of Environmental Science and Technology, 12(2), 763-774. https://doi.org/10.1007/s13762-014-0571-6

Yu, X.-Z.and Feng, X.-H., 2016, Effects of trivalent chromium on biomass growth, water use efficiency and distribution of nutrient elements in rice seedlings. Applied Environmental 
Biotechnology, 1(1), 64-70.

http://doi.org/10.18063/AEB.2016.01.005

Yu, X.Z., Gu, J.D. and Liu, S., 2007. Biotransformation and metabolic response of cyanide in weeping willows. Journal of Hazardous Materials, 147(3), 838-844.

https://doi.org/10.1016/j.jhazmat.2007.01.081

Yu, X.Z., Lu, P.C. and Yu, Z., 2012. On the role of $\beta$-cyanoalanine synthase (CAS) in metabolism of free cyanide and ferricyanide by rice seedlings. Ecotoxicology, 21(2), 548-556. https://doi.org/10.1007/s10646-011-0815-x

Yu, X.Z., Peng, X.Y. and Wang, G.L., 2011. Photo induced dissociation of ferri and ferro cyanide in hydroponic solutions. International Journal of Environmental Science \& Technology, 8(4), 853-862.

https://doi.org/10.1007/BF03326268
Yu, X.Z., Trapp, S., Zhou, P.H., Wang, C. and Zhou, X., 2004. Metabolism of cyanide by Chinese vegetation. Chemosphere, 56(2), 121-126.

https://doi.org/10.1016/j.chemosphere.2004.02.008

Yu, X.Z., Trapp, S. and Zhou, P.H., 2005. Phytotoxicity of cyanide to weeping willow trees. Environmental Science and Pollution Research, 12(2), 109-113.

https://doi.org/10.1065/espr2005.02.237

Yu, X.Z. and Zhang, F.F., 2017, Distribution of phenolic compounds in rice seedlings under $\mathrm{Cr}$ exposure. Applied Environmental Biotechnology, 2(1), 29-36. http://doi.org/10.18063/AEB.2017.01.004 